\title{
Strategies for Improving the Performance of Higher Learning Institutions in Tanzania
}

\author{
Francis Muya ${ }^{1} \&$ Hawa Tundui ${ }^{2}$
}

\author{
${ }^{1 \& 2}$ School of Business, Mzumbe University, Morogoro, Tanzania \\ Correspondence: Francis Muya, Department of Business and Entrepreneurship Studies, National Institute \\ of Transport (NIT), Dar es Salaam, Tanzania. \\ Email: mgosimuya@gmail.com
}

$$
\text { doi:10.23918/ijsses.v7i1p27 }
$$

\begin{abstract}
The role of higher learning institutions (HLIs) is increasingly becoming important in contributing to socio-economic development in nations year after year. HLIs cannot fully play their roles unless proper strategies are in place. This study explored strategies which can improve the performance of HLIs using 39 respondents who were purposively selected. Data were collected using an interview guide and thematically analyzed with the help of QDA Miner Lite tool for qualitative data. Strategies which are essential for HLIs performance includes, observance of ethics by management and staff in HLIs, uses of competent lecturers, production of best graduates, development of sound learning environment, being connected with different stakeholders, being socially responsible, undertaking marketing efforts and struggling to attain high degree of reputation. This study concludes with recommendation that HLIs who want to prosper in the current environment has nothing to do than putting in place proper strategies.
\end{abstract}

Keywords: Strategies, Higher Learning Institutions, Qualitative, Challenges

\section{Introduction}

Higher learning institutions (HLIs) in Tanzania and globally are facing many challenges which impact their performance in terms of enrollment and retention of students, university and technical higher education coverage, production of best graduates, competitiveness and on quality of teaching. Tanzania HLIs are facing the lowest gross tertiary enrolments ratio (4.0\%) than nearby countries like Kenya (9.2\%), Rwanda (7.6\%) as well as other African countries like Sudan (17\%), Botswana (30.2\%) and Algeria $(36.8 \%)$. When these rates are compared with other countries in the world like Australia (118.6\%), the rates in Tanzania are very low (UNESCO, 2015).

The distributional geographical coverage of HLIs is very low when compared with the size of the country and its geographical nature. According to Tanzania Commission for University (TCU) (2018) out of sixtyfour (64) HLIs which enrolled students in the academic year 2018/2019, two regions of Dar es Salaam and Morogoro, have twenty-eight (28) HLIs which is equal to $44 \%$ of all HLIs available in Tanzania. The remaining HLIs, thirty-six (36) which is equal to $56 \%$, are shared by other regions in mainland Tanzania and Zanzibar (TCU, 2018). This geographical distribution of HLIs is contrary to the University Act, 2005, University Act (General Regulations), 2013, Education and Training Policy (2014), Vision 2025 and even the Sustainable Development Goals (SDGs), which all emphasize the need for improved quality education as well as increased access and equity to higher education. 
Tanzania HLIs are blamed to produce graduates which lacks the required competence and skills level, who cannot also employ themselves hence increasing the number of jobless graduates in the country (Mpanju, 2012; Nangale, 2012; Ndyali, 2016; Tan, Bashir \& Tanak, 2015; United Republic of Tanzania (URT), $2014,2016)$. The problem is becoming very serious due to limited employment opportunities in the country (which was 1.9\% in 2019) and even globally which was $4.95 \%$ at the end of year 2019 (International Labour Organization (ILO), 2019).

In overall terms, Tanzania is performing poorly in higher Education and Training component as revealed by Global Competitiveness Report (2017/2018), where the country is ranked 130 out of 137 scoring 2.6 out of 7 scores in Higher Education and Training sub index (Klaus, 2017). Among the strategies which can be adopted by HLIs in order to neutralize the stated challenges, is to become marketing oriented which is seen as a means to meet their service objectives including delivering quality services, better understanding of customers and competitors, increasing market share, profit, innovativeness and hence become competitive both domestically and internationally. Other benefits include, increasing professional reputation, improving facilities and faculty, developing enrolment and endowment, adapting to demands in the society, and increasing accessibility to financial resources (Dolnicar \& Lazarevski, 2009; Maringe, 2006; Sharp, 2007; Stachowski, 2011; Lichiello, 2014; Shepherd, 2008).

Marketing orientation as a strategy in HLIs is however receiving various criticisms on its suitability in HLIs contexts (Barrett 1996; Nicolescu, 2009; Gibbs, 2011; Rotfeld, 2008). Given such kind of critisms on marketing in HLIs, complex environment where HLIs operates, and taking into account that the country is moving towards nurturing industrialization for economic transformation and human development (URT, 2016), rethinking of proper strategies for optimal HLIs performance is increasingly becoming important. This paper presents a number of strategies which can enable HLIs to neutralize the stated weaknesses hence attainment of institutional and national goals.

\section{Literature Review}

Describing the necessity for rethinking best strategies in a university setting, PricewaterhouseCoopers Consulting (2018) argued that universities are currently facing competitive pressures which are driven with a number of key factors. These are such as, increasing student expectations, internationalization of higher education which imply that students have a wider choice of where to study, government emphasis on results of its spending given the greater outlays under a demand-driven system, hardness in securing research funding than in the past, competitive market for high-performing academics and digital competition from other universities and non-universities. In such kind of environment, the major efforts must be directed at improving overall academics through various strategies including setting performance exceptions and development plans, reviewing discipline participation, focusing on academics' strengths, selective recruiting and partnering to access complementary strengths. The report is concluded with a number of lessons from universities which achieved greater level of academic performance. The lessons include, being clear on performance expectations, utilization of performance data, undertaking performance discussion with different academician, focus on non-financial factors when retaining staff and recruiting high performers, encourage academics to be able to choose the career path that suits them and commit to long term career models. These findings are supported by Long et al. (2016), who found a 
positive relationship between the competence of a lecturer and performance of a student. Pargett (2011) found a significant and positive relationship between academic advising and student development as well as with student satisfaction with college, issues which are important for HLIs performance.

Presenting potential strategies in higher learning institutions, Lumina Foundation (2015) maintained that improving the yields in higher education require different measures including, performance funding where targeted incentives for colleges and universities to graduate more students with high-quality degrees and credentials is assured; and provision of student incentives through strategic use of tuition and financial aid to incentivize course and program completion. Other measures included adoption of new models which can take a form of lower-cost, high-quality approaches substituted for traditional academic delivery to increase capacity for serving students; and business efficiencies which involve business practices that produce savings to graduate more students. The role of financial resources for students' success and overall HLIs performance was also noted by Hannover Report (2014).

Proposing strategies on how to drive successful marketing practices in the banking sector, Lwiza and Nwankwo (2002) suggested various alternatives including mobilizing private savings, deepening branch networks, establishing mechanism for dealing with environmental shocks, and allowing higher degree if intermediation from outside the market place. HLIs can learn from these activities in order to expand accessibility of services they are providing. The issue of deepening branches networks is related with the issue of improving HLIs geographical coverage suggested by Tan et al. (2015) as among the strategies for overcoming gaps in workforce skills.

As a strategy to improve their academic reputations, Conard and Conard (2000) claimed that HLIs need to consider a number of issues including, encouraging students to participate in career development activities, encouraging well-known organizations to actively recruit on campus, and to communicate the level of faculty involvement in teaching and contact with students, Other issues were development of policies and procedures, consistent with the mission of the institutions, which would reduce the percentage of courses and students taught by teaching assistants; maintain up to date technological facilities; and design curricula to provide students with an education full of the requisite knowledge and skills (e.g., current theories and critical thinking) to engage in successful careers.

Recommending strategies for improving the performance of higher education service in Malaysia, Hussin, Soon, and Sidin (2000) pointed out a number of options including, serving of customers' needs, ensure the quality of teaching, improve college images and reputation and the surrounding of the campus which all are essential for attracting students. Other strategies included offering of distinctive unique experience to students, dissemination of information through different tools like television, radio, education fairs, as well as national wide visits by representatives from the institutions. The use of facilities such as multimedia technology and ICT in all means of service deliveries, recruiting and training of best staff with much experience on research and business experience is also very important. Ackerman and Schibrowsky (2007) found presence of well-trained employees as essential for organization performance. Zebal and Goodwin (2012) also found the consideration of students' need in HLIs context as very important. Mokaya (2013) found a significant relationship between physical resources and students' retention. 
Different strategies in order to improve higher education institutions' performance were presented in this section. The measures cannot however be generalized across all HLIs in the world making necessary for a specific study in Tanzania.

\section{Methodology}

\subsection{Research Design}

This study was qualitative (mono-method choice) in nature, adopting a case study strategy, trying to build a theory on HLIs strategies (inductive) in a cross-sectional time horizon (Saunders, Lewis, \& Thornhill, 2007).

\subsection{Sampling Procedures and Sample Size}

Non-probability sampling especially convenient and purposive sampling were used to select two regions as areas of study (Dar es Salaam and Morogoro), ten (10) HLIs, ten (10) employers, ten (10) graduates, ten (10) students and ten (10) staff in each HLIs. The expected sample size was therefore 40 respondents. Among ten (10) HLIs, one (1) did not invite the researcher for data collection.

\subsection{Data Type and Data Collection Methods}

Primary data were collected using an interview guide which contained a number of closed ended questions (demographic characteristics of the respondents) and open ended questions (strategies for enhancing the performance of HLIs).

\subsection{Reliability and Validity Analysis}

According to Creswell (2009) qualitative reliability indicates that the researcher's approach is consistent across different researchers and different projects. On the other hand, qualitative validity means that the researcher checks for the accuracy of the findings by employing certain procedures. Reliability of qualitative data in this study was ensured by testing the questions with a number of respondents and checking the transcripts to make sure that they do not contain obvious mistakes made during transcription (Cresswell, 2009). Validity was ensured through member check method where three (03) participants in the interview, were invited to check the findings and results and give feedback if they find themselves in or not (Cresswell, 2009; Grossoehme, 2014, Kanis, 2014).

\subsection{Data Analysis}

Though qualitative data can be analyzed using different methods such as Grounded Theory Method (GTM), semiotics, and conversation analysis (Babbie, 2007) thematic analysis method (Castleberrya \& Nolenb, 2018; Clarke \& Braun, 2016; Scharp \& Sanders, 2018) was used to analyze data in this study with the help of QDA Miner Lite software. 


\section{Findings}

\subsection{Demographic Characteristics of the Respondents}

A total of thirty-one (31) respondents participated in the interviews of this research. Among these $93.5 \%$ were from public corporations, one (1) from local government organization, and 3.2\% was from a private organization. Majority of the respondents' age, fell under two groups of 31-40 (38.7\%) and between 4150 (32.3\%). Regarding their status/occupations, $32.3 \%$ were employers' representatives, $29 \%$ were staff in the Quality Assurance Bureaus/Centers which included directors of quality assurance and quality control coordinators. Another group which participated in the interviews were students' leaders which included presidents, prime ministers and ministers (29\%), and graduate from five (05) HLIs (16.1\%). Regarding their level of education, majority of the respondents (45.2\%) had a bachelor degree/doing bachelor degree studies, $38.7 \%$ had masters' degrees, $12.9 \%$ had a doctor of philosophy degree, and 1 respondent had a postgraduate diploma. These characteristics are presented in Table 1.

Table 1: Respondents' Characteristics

\begin{tabular}{|l|l|l|l|}
\hline Characteristics & & $\mathrm{n}=31$ & $\%$ \\
\hline \multirow{2}{*}{ Nature } & Public Corporation & 29 & 93.5 \\
& Local Government & 1 & 3.2 \\
& Private organization & 1 & 3.2 \\
\hline \multirow{2}{*}{ Age } & $20-30$ & 9 & 29 \\
& $31-40$ & 12 & 38.7 \\
& $41-50$ & 10 & 32.3 \\
\hline \multirow{2}{*}{ Status } & Director of Quality/ Quality Assurance Coordinator & 7 & 22.6 \\
& Employers' Representative & 10 & 32.3 \\
& Student Leader & 9 & 29 \\
& Graduate & 14 & 16.1 \\
\hline \multirow{2}{*}{ Education } & Degree & 1 & 3.2 \\
& Postgraduate Diploma & 12 & 38.7 \\
& Master & 4 & 12.9 \\
\hline
\end{tabular}

\subsection{Strategies Related Themes that Emerged in the Interviews}

Several themes emerged after careful review of the transcripts. The themes focused on the strategies which can enhance the performance of Tanzania HLIs in terms of retaining students, quality teaching, being competitive and having high reputation. The themes were the "Observance of Ethics", "Competent Lecturers", "The Role of Best Graduates", "Sound Learning Environment", "Being Connected", "Focusing on Student's Needs", "Best Curriculum" Corporate Social Responsibility" and "Other Strategies". These themes are explained here below and next, a detailed discussion follow. 


\subsubsection{Observance of Ethics}

The word ethics appeared on the transcripts 20 times indicating that a good number of respondents viewed "observing ethics" as among the best strategies in the current environment where HLIs operates. The respondents emphasized that HLIs staff must observe their code of ethics in order to serve students impartially but also in order to dedicate their full capabilities to their responsibilities in HLIs. One respondent emphasized academic staff to "protect the name of their institutions, avoid any types of scandals, and avoid self and conflict of interest and ensure high degree of professionalism". HLIs were encouraged to issue certificates strictly to those who deserve after attaining required grades. HLIs must also separate politics from academics and stick to quality. Respondents indicated that ethical culture is important in attracting and retaining students, HLIs reputation and competitiveness.

\subsubsection{Competent Lecturers}

As another strategy, the majority of the respondents especially from among employers, advised HLIs to use qualified, motivated (through accommodation and transport) and competent academic staff. One respondent said that "If lecturers are well motivated they will not move from one organization to another performing different activities on a part time basis. This will enable them to get enough time for preparing themselves and be available to serve varying students' needs. The number also must be enough as per the required guidelines in order to minimize the usage of part-time lecturers that increase expenses to HLIs but also with divided royalty. They are also not full available for students and sometimes fail to perform their assigned duties perfectly". Furthermore respondents advised the need to improve lecturers competence through further training and exposure to other HLIs which are within and outside the country (e,g through exchange programs). In one HLI a programme known as University Teaching and Learning Improvement Programme (UTLIP) was used as both a programme for enhancing teaching competence but also as a strategy to prepare those who join the academic profession. The duration of teaching methodology courses given to academic staff, can also be added instead of three, five or few days per year. Respondents emphasized that the suitability of the academic staff should not be judged based on Grade Point Average (GPA) but base on serious assessment and supervision of his/her teaching task. One respondent advised that "lecturers must also do some examinations in order to improve their competence and force them to be up-to-date". The working environment in the form of offices and teaching equipment must also be attractive. Respondents also advised on the presence of succession plans for academician and encouraging professors and other senior staff to mentor junior staff. Creating such environment for staff and academic staff specifically, is essential for making them committed and innovative, things which may have positive contributions on the quality of teaching which may lead to HLIs reputation and competitiveness.

\subsubsection{Best Graduates}

Respondents commented that various performance metrics in HLIs like reputation and competitiveness are highly dependent on the graduates which come from them. They therefore advised HLIs to take a serious note on the graduate they are producing. Among the views of the respondents was that "if HLIs produce best graduates, when they are employed in different organizations and deliver as per employer expectations they create a very strong reputation for their HLIs". Best graduates were seen as among the 
best tools for marketing the HLIs rather than HLIs spending a lot of effort marketing themselves. The graduates must not only demonstrate excellence when they are employed but also they must be in a position to employ themselves and others. HLIs that can be in position to produce such graduates are assured of success in students' attraction and retention, high reputation and competitiveness. Respondents advised that each output of HLIs must be of highest quality.

\subsubsection{Sound Learning Environment}

Respondents advised that HLIs must have best environment for offering education including presence of modern buildings, availability of adequate and up-to-date facilities like laboratories, computers, lecture rooms, private studies areas, library, student accommodation and reliable internet. Respondents also advised HLIs to use and go with modern technology in teaching and interacting with students to cope with the digital world, improve the teaching process, be sensitive with big number of students and ensure availability of enough teaching facilities. Among the views of the respondents was that "provision of better services and quality education in good environment remain in the mind of graduates hence plans to come back". The importance of improving the physical appearance and environment was also recognized.

\subsubsection{Being Connected}

Respondents advised that HLIs must have connection with their graduates, employers, and even other HLIs. The respondents were aware that this is ensured through a number of ways like tracer studies and in relation to this one respondent commented that "some HLI are undertaking tracer studies to establish where their graduates are working. It seems there are no serious efforts to establish who and where are those who are in self-employment. Interacting with these people who are in self-employment can offer valuable information to HLIs on what can be done to enhance graduates' self-employment as un-employment is a serious problem in the country and the world at large". The respondent added "such individuals whether successful or not can also be invited to a HLI to share experience on what made them to be on the current status". Respondents therefore advised that HLIs must make follow-up of every graduate to establish what he/she is doing and have a specific database for such information, and HLI to establish connection with organizations performing related activities including signing of Memorandum of Understanding (MoU). Furthermore, respondents advised on the presence of scholarship at the undergraduate and masters level, having multiple courses to encourage studies continuity and specialization. Other strategies for enhancing connections in HLIs are through having regular contacts and arrangements for meeting graduates and alumni. It was advised that this can be possible through presence of active office (like retention coordinators advised by Hannover Report, 2014) to deal with alumni, use of social networks like WhatsApp, Facebook, Instagram and Twitter in order to connect and continually interact with alumni. Students must be allowed to join such platforms since they are on studies or in their final years of studies. HLIs must consider interacting with western universities and give exposure to students to make them confident to meet the demand of the market. HLI must also learn from successful foreign HLIs on what they did in order to have trusted teaching quality. Such strategies are important for enhancing students' retention, reputation and competitiveness of HLIs. 


\subsubsection{Focusing on Students' Needs}

Respondents advised HLIs to take students need into account taking into account that these are important stakeholders that make HLIs survive. The importance of customer care and the use of staff that show warmth and helpfulness was highly acknowledged. HLIs must take initiative to see and solve any challenges facing students, as one respondent said "HLIs must be close to students and make sure their needs are honored. HLIs are not bosses to students, but students are bosses to HLIs". HLIs must ensure good relationship with students and make students have enough time and opportunity to interact with lecturers. A strong system to monitor compliance with service standards at HLIs must also be in place. The experience obtained during the data collection phase revealed that majority of HLIs are performing well on this through presence of academic advisor, dean's office and head of departments though the entirety of students mentoring is not considered.

\subsubsection{Best Curriculum}

A number of issues were raised by the respondents in relation to the curriculum which are used by HLIs. Among the views were that HLIs must change their curriculum in line with the market demand. This means that sometimes HLIs may be required to phase out some courses due to lack of demand in the market. The curriculum must ensure right students are enrolled in terms of high school scores (HLIs must avoid taking students which are rejected by other HLIs), ensure provision of quality education and internationalize themselves. Curriculum must be developed in such a way that students are trained to be capable for self-employment through practical training on courses which solve many challenges in the community. Many respondents were against traditional methods of delivering materials to students especially lecturing methods and traditional methods of assessing students such as tests which make students to have many theories in mind than practical. Other respondents were against the system of form six students joining the HLIs and advocated studies from National Technical Award (NTA) level as the best entry to the University education.

A good number of respondents emphasized the need for having strong quality assurance units which must be empowered and not interfered in the course of performing their duties. The respondents said that there must be quality coordinators in every department and who are active. One respondent commented that "quality assurance people must be aware that quality in a HLIs is not built on inspection but in many activities before student join the university, when he joins the university and his/her entire life at a HLI". Respondents required TCU to strength HLI Quality Assurance Bureaus through fees they are charging. It was advised that HLIs must stop using outdated curricula especially on areas with fast changes like Engineering and ICT. Some respondents had emphasis on Competence-Based Education and Training (CBET) rather than Knowledge-Based Education and Training (KBET) in order to have graduates with practical experience who can work perfectly as employees and as employers. On the methods of learning and assessments, curriculum must emphasize enough number of hours where students are supposed to work for a number of months as important component in his/her years of studies. HLIs must seek various source of funding and cooperate with employers in order to offer some compensation to students on work. Curriculum must state the uses of interactive approaches and simulation. In addition, the respondent required HLIs to be unique from other education providers-to have their own identity, and avoid offering 
courses that everybody is offering. As HLIs operates under regulators, they must follow all directives, guides and standards issued by these institutions. The strategies mentioned here are essential for having quality teaching, improvement in retention, reputation and competitiveness of HLIs.

\subsubsection{HLI Social Responsibility}

Respondents said that HLIs in the course of undertaking their daily activities must also take into account the interest of the societies. HLIs must produce important people for the market, who are good in head and not in paper who are in a position to solve different social problems. HLIs must undertake research, disseminate and implement the findings hence benefiting the societies. HLIs must transfer the training to the public (externalization rather than internalization of training). Such activities are important for enhancing HLIs reputation and competitiveness.

\subsubsection{Other Strategies}

The respondents also suggested a number of strategies which are essential for HLIs performance including having high reputation, undertaking marketing efforts, publishing books and sell to famous site like Amazon, attracting foreign students, having short duration programs and running executives programs which are tailor made and do not interfere learners timetable. Sticking to regulations, principles and guidelines issued by the regulators and internal ones-such as admission qualifications was also highly emphasized by the majority of the respondents. HLIs are also supposed to stick to their core functions.

\section{Discussion}

Due to many challenges in the environment that HLIs operates, marketing orientation is among the best strategy for enhancing the performance of HLIs. As pointed out earlier, marketing orientation is a new strategy in HLIs and it is facing very many challenges. While exploring avenues for taking advantage of the benefits of being marketing oriented, the researcher felt important to explore some strategies which can enable HLIs to survive in the current dynamic and challenging environment. A number of themes were identified in relation to the strategies which can be adopted by HLIs in order to enhance students' retention, quality teaching, reputation and competitiveness. These themes are hereunder explained. Observance of ethics was stated as among the best strategies in the current environment where HLIs operates. The respondents' opinions were also supported by TCU (2019) which require every university to observe ethics, transparency, and academic integrity throughout the teaching, learning and research activities in the institution, and in community engagement. Since this is coming from TCU, it is not optional but a must do thing by every HLIs. The importance of ethics in higher education context is also emphasized in a study by Rezaee, Elmore and Szendi (2001). Motlagh, Jamali and Ghoorchian (2016) found ethics as very important for quality improvement in higher education. Majority of the respondents especially from among employers, advised HLIs to use qualified, motivated and competent academic staff. These views are in line with those by Ackerman and Schibrowsky (2007) who recognized the importance of presence of welltrained employees to provide accurate information and friendly responses to inquiries. Rajh and Došen (2009) and Castro et al. (2005) are among studies that stresses the importance of employee in the market orientation and performance of organizations. 
Among the views of the respondents was that best graduates have potentials to create a very strong reputation for their HLIs. Hussin et al. (2000) found that the marketability of degree obtained by graduates, is essential for HLIs performance. A study by Martensen and Grønholdt (2005) found a strong connection between graduates competences and reputation of higher education institutions. Lumina Foundation (2015) advised colleges and universities to graduate more students with high-quality degrees and credentials. The findings are supported by Whang (2017) who found a close relationship between product quality and firm performance in for-profit organizations.

Respondents advised maintenance of sound and conducive learning environment in HLIs as another strategy for their optimal performance. In the same line of thought Mokaya (2013) view improved academic achievement and retention as associated with more adequate and well-spaced classrooms, adequate and ample spacing in the libraries, adequate science laboratories, adequate water and sanitation facilities and adequate participation in co-curricular activities. Lau (2003) found that physical facilities like dormitories, study rooms, facilities for the disabled, career centres, social and professional organizations and computer technology are essential in students' retention in any education setting. Ithal (2016) also stressed the importance of those resources like IT facilities, online information and database subscription through national library network. Conard and Conard (2000) advised HLIs to maintain up to date technological facilities as essential stage for a conducive teaching and learning environment.

Being connected with graduates, employers, and even other HLIs is another strategy which can improve the performance of Tanzania HLIs. In relation to this, respondents advised the presence of scholarship at the undergraduate and masters levels which is line with the views of Ackerman and Schibrowsky (2007) who advocated financial bonds in higher learning institution through scholarships, work-study opportunities, transportation, on campus housing, tuition discounting, financial aid package, subsidized student health insurance programs and no interest emergency loans. Hannover Report (2014) advised redesigning of scholarship and bursary in order to enhance students' retention, social bonding (including all interpersonal interactions that exist such as student-advisor, student instructors, students administrative staff, accessible faculty and support staff. According to Lumina Foundation (2015) strategic use of tuition and financial aid to incentivize course and program completion and adoption of new models which can take a form of lower-cost, high-quality approaches are among the best strategies for enhancing the performance of HLIs. Furthermore, the respondents advised HLIs to focus on students' needs as another strategy for their optimal performance. Hemsley-Brown and Oplatka (2010) found focusing on students' needs (customer orientation) as very important in higher education context. These views are in line with those of Ackerman and Schibrowsky (2007) who emphasized social bonding in a higher education context including all interpersonal interactions that exist such as student-advisor, student instructors, students administrative staff, accessible faculty and support staff. According to Hussin et al. (2000) for higher education to improve their performance they must consider serving their customers' needs which can help attracting many of them. According to Zebal and Goodwin (2012) when careful attention is being paid to the concern of students, there is a strong positive association with teaching outcomes and associated services hence decision of students to stay at the institutions. Domański (2014) require HLIs to turn their attention even to foreign students. 
Among the issues suggested by the respondents as indicator of best curriculum was the issues of students' engagement. This idea was also proposed by Domański (2014) who advised that educational services should be developed interactively in cooperation with key stakeholders. Similar importance was also observed by Ackerman and Schibrowsky (2007) who underscored students' participation in decision making as well as Sezgin and Binath (2011) who found that curricula with novelty and flexibility as well as language of instruction are among the significant factors in firm's competitiveness.

A number of issues were raised by the respondents in relation to the curriculum which are used by HLIs. Among the views were that HLIs must change their curriculum in line with the market demand. Conard and Conard (2000) advised HLIs to design curricula to provide students with an education full of the requisite knowledge and skills (e.g., current theories and critical thinking) to engage in successful careers. Respondents also emphasized the need for having strong quality assurance unit in HLIs. Whang, (2017) found that product quality is essential in shaping firm's competitiveness. A study by Yorke (1999) found a number of measures for enhancing quality teaching in HLIs, including presence of quality assurance mechanisms both internally and externally, establishing collaborative arrangements with institutions abroad that are best in teaching quality, interference by professional bodies, and attaining certification like ISO 9000. Dwyer and Kim (2003), Whang, (2017) and Sun and Pang (2017) all viewed the quality of service as among the resources which are essential for firm's national and global competitiveness. Respondents also advised HLIs to be socially responsible. Importance of CSR was also recognized by Llyod-Smith and An (2019) who found that corporate social responsibility activities (CSR), and industry level CSR spillover, positively contributes to firm reputation. HLIs must undertake research and disseminate and implement the findings hence benefiting the societies. This argument is supported by Zhang et al. (2017) who emphasized on the need of HLIs to collect information and disseminate results as critical activities which have implication on competitiveness and hence high reputation.

Another proposed strategy for enhancing performance in HLIs was undertaking marketing efforts. This view is supported by Hemsley- Brown and Oplatka (2006) who found potential benefits of applying marketing theories and concepts that have been effective in the business world hence gradually being recognized by researchers in the field of higher education (HE) marketing. Maringe $(2004,2005)$ asserted that HLIs are experiencing tougher competition to attract students from rivals and that University managers and academics need to consider the marketing as a viable philosophy and strategy. Dwyer and Kim (2003) also recognize the role of marketing management function in a business setting. A study by McGrath (2000) found supports of marketing practice in a HLI context. Motekaitiene and Juscius (2008) views the ties between marketing and higher education as unavoidable in today's society. A study by Tabaku and Mersini (2013) found that non-profit organizations view marketing as important for their success. Stachowski (2011) view marketing orientation as among the best marketing practice in higher education institutions context. Other respondents advised HLIs to make sure they raise their reputation, a suggestion which is close to Smith, Rupp, and Motley (2013) and Munisamy, Jaafar and Nagaraj (2013) who found corporate reputation as an edge for competitive advantage. Hussin, Soon, and Sidin (2000) viewed improving college images and reputation as among the best strategies in the higher education setting. Beneke and Human (2010) found reputation of the institution as the most important factor in a scholar's decision of a place of further studies. 


\section{Conclusion and Recommendations}

This study has successfully presented a number of strategies which must be adapted by HLIs in order to have optimal and sustainable performance. The strategies are not quite different from those pointed out by previous literatures and they revolve around having dedicated efforts within the HLIs' environment by ensuring ethical and conducive learning environment and focusing on students' needs, as well as presence of dedicated efforts to the external environment through being socially responsible. The stated strategies are very important due to the nature of the current environment where HLIs operates which is full of forces related to globalization, competition, increased societal expectations, limited financial resources, limited employment opportunities and low HLIs geographical coverage. All these forces necessitate well thought strategies which can enhance the performance of HLIs sustainably. This study was qualitative in nature involving only nine (09) HLIs in Tanzania. Future mixed studies involving a large number of HLIs can improve the results hence improved decisions for optimal HLIs performance. Studies on the specific effects of each strategy stated in this research can also be undertaken.

\section{References}

Ackerman, R., \& Schibrowsky, J. (2007). A business marketing strategy applied to student retention: A higher education initiative. Journal College Student Retention, 9(3), 307-336.

Aithal, S. (2016). How to increase research productivity in higher educational institutions (SIMS Model), MPRA Paper No. 71750, Srinivas Institute of Management Studies, Pandeshwar, Mangalore, India.

Babbie, E. (2007). Practice of social research (11th ed.). United States of America: Thomson Vvadsvvorth.

Barrett, L.R. (1996). On students as customers some warning from America. Higher Education Review, 28(3), 70-1.

Beneke, J., \& Human, G. (2010). Student recruitment marketing in South Africa: An exploratory study into the adoption of a relationship Orientation. African Journal of Business Management, 4(4), 435-447.

Caruana, A., Ramaseshan, B., \& Ewing, M.T. (1998). Do universities that are more market oriented perform better? International Journal of Public Sector Management, 11(1), 55-70.

Castleberrya, A., \& Nolenb, A. (2018). Thematic analysis of qualitative research data: Is it as easy as it sounds? Currents in Pharmacy Teaching and Learning, 10(6), 807-815. doi: 10.1016/j.cptl.2018.03.019,

Castro, CA., Armario, E.M., \& del Río, M.E.S (2005). Consequences of market orientation for customers and employees. European Journal of Marketing, 39(5/6), 646-675.

Clarke, V., \& Braun, V. (2016). Thematic analysis. The Journal of Positive Psychology, 12, 297-298. doi:10.1080/17439760.2016.1262613.

Claus, S. (2017). The Global Competitiveness Report 2017-2018. World Economic Forum.

Conard, M. J., \& Conard, M. A. (2000). An analysis of academic reputation as perceived by consumers of higher education. Journal of Marketing for Higher Education, 9(4), 69-80.

Creswell, J.W. (2009). Research design: Qualitative, quantitative, and mixed methods approaches, (3rd ed.). Singapore: SAGE Publications Asia-Pacific Pte. Ltd.

Dolnicar, S., \& Lazarevski, K. (2009). Marketing in non-profit organizations: An international perspective. International Marketing Review, 26 (3), 275-291.

Domański, T. (2013). Marketing of higher education: Future challenges. Management and Business Administration, 22(4) (127), 118-132. 
Dwyer, L., \& Kim, C. (2003). Destination competitiveness: Determinants and indicators. Current Issues in Tourism, 6(5), 369-414.

Estermann, T., Pruvot, E.B., \& Claeys-Kulik, A. (2013). Designing strategies for efficient funding of higher education in Europe. European University Association, Brussels, Belgium.

Grossoehme, D.H. (2014). Overview of qualitative research. Journal of Health Care Chaplaincy, 20(3), 109-122.

Hanover Research (2014). Strategies for Improving Student Retention.

Hemsley- Brown, J., \& Oplatka, I. (2006). Universities in a competitive global marketplace: A systematic review of the literature on higher education marketing. International Journal of Public Sector Management, 19 (4), 316-338.

Hussin, S.R., Soon, T.H., \& Sidin, S. (2000). Marketing analysis of the higher education service sector in Malysia: Consumer perspective. Pertanika J. Soc. Sci. and Hum, 8(1).

International Labor Organization (ILO). (2019). World Development Indicators.

Ivy, J. (2001). Higher education institution image: A correspondence analysis approach. The International Journal of Educational Management, 15(6), 276-82.

Kanis, H. (2014). Reliability and validity of findings in ergonomics research. Theoretical Issues in Ergonomics Science, 15(1), 1-46.

Lau, L.K. (2003). Institutional Factors Affecting Students Retention. Education, 124 (1), 126-136.

Lichiello, P.C. (2014). The Graduate retention relationship cycle: the role of performance, engagement, satisfaction, and alienation. Lynchburg College Theses and Dissertations. Paper 1.

Lloyd-Smith, P., \& An, H. (2019). Are corporate social responsibility and advertising complements or substitutes in producing firm reputation? Journal of Applied Economics, 51(21).

Long, S.T., Kowang, T.O., Fei, G.C., \& Jusoh, A. (2016). The Linkage of lecturers' competencies \& student performance: A case study in Malaysia. The Social Sciences, 11 (3), 297-300.

Lumina Foundation (2015). Improving the Yields in Higher Education, United States of America.

Lwiza, D.R.B., \& Nwankwo, S. (2002). Market-driven transformation of the banking sector in Tanzania. International Journal of Bank Marketing, 20, 38 - 49.

Maringe, F. (2004). Vice chancellor's perceptions of university marketing: A view from universities in a developing country. Higher Education Review, 36(2), 53-68.

Maringe, F. (2005). Interrogating the crisis in higher education marketing: The CORD model. International Journal of Educational Management, 19(7), 564-578.

Maringe, F. (2006). University and course choice: Implications for positioning, recruitment and marketing. International Journal of Educational Management, 20(6), 466-479.

Martensen, A., \& Grønholdt, L. (2005). Reputation in higher education: Development, validation and application of a model. Center for Marketing Communication. Department of Marketing, Copenhagen Business School.

McGrath, J.M. (2002). Attitudes about Marketing in Higher Education: An exploratory study. Journal of Marketing for Higher Education, 12(1), 1-14.

Mokaya, Z.M. (2013). Influence of School Infrastructure on Students' Performance in Public Secondary Schools in Kajiado County, Kenya (Unpublished master's thesis). University of Nairobi.

Motekaitiene, A., \& Juscius, V. (2008). Specifics of Marketing in the Higher Education System. Social Research, 12(2), 97-103.

Motlagh, M.L., Jamali, A., \& Ghoorchian, N.G. (2016). The role of spirituality and ethics in higher education quality improvement. Management Science Letters, 6, 341-350.

Mpanju, A. (2012). Employment impact of foreign direct investment. Lambert, Academic Publishing.

Munisamy, S., Jaafar, N.S.M., \& Nagaraj, S. (2013). Does reputation matter? Case study of undergraduate choice at a premier university. Asia-Pacific Education Researcher, 23(3), 451462. 
Nangale, G. (2012). The role of the state in economic development: Employment challenges in Eastern Africa-The Case of Tanzania: A Country Paper Presentation at the Friedrich Ebert Stiftung (FES) Eastern African Conference on Employment Policies in Nairobi, Kenya. September 2425.

Ndyali, L. (2016). Higher education system and jobless graduates in Tanzania. Journal of Education and Practice, 7(4).

Newman, C.N. (2002). The current state of marketing activity among higher education institutions. Journal of Marketing for Higher Education, 12(1), 15-29.

Nguyen, N., \& LeBlanc, G. (2001). Image and reputation of higher education institutions in students' retention decisions. The International Journal of Educational Management, 15(6), 303-11.

Nicolescu, L. (2009). Applying marketing to higher education: scope and limits. Management and Marketing, 4(2), 5-44.

Pargett, K.K. (2011). The Effects of academic advising on college student development in higher education. Theses, Dissertations, and Student Research. 81.

Polat, G., \& Donmez, U. (2010). Marketing management functions of construction companies: Evidence from Turkish contractors. Journal of Civil Engineering and Management, 16(2), 267-277.

PricewaterhouseCoopers Consulting. (2018). Strategy and Improving the Performance of University Academics: Lessons from Australia, Australia.

Rajh, E., \& Došen, D.O. (2009). The Effects of marketing mix elements on service brand equity. Economic Research, 22(4), 69-83.

Rezaee, Z., Elmore, R.C., \& Szendi, J.Z. (2001). Ethical behavior in higher educational institutions: The role of the code of conduct. Journal of Business Ethics, 30, 171-183.

Rotfeld, H.J. (2008). The largest segments that should not be served: higher education marketing serving the growing slacker segment. Journal of Consumer Marketing, 25(6), 378-380.

Saunders, M., Lewis, P., \& Thornhill, A. (2007). Research methods for business students (4th ed). New York: Prentice Hall.

Scharp, K.M., \& Sanders, M.L. (2018): What is a theme? Teaching thematic analysis in qualitative communication research methods. Communication Teacher, 33(2), 117-121. doi: 10.1080/17404622.2018.1536794.

Sezgin, A., \& Binath, A. (2011). Determinants of university choice in Turkey. International Higher Education Congress Proceedings, 3(12), 1651-1657.

Sharp, B. (2007). Marketing orientation: More than just customer focus. International Journal of Wine Marketing, 3(1), 20-25.

Shepherd, I.D.H. (2008). The application of marketing thinking to student retention. Planet, 19(1), 2630.

Smith, A.D., Rupp, E.W., \& Motley, D. (2013). Corporate reputation as strategic competitive advantage of manufacturing and service-based firms: multi-industry case study. Int. J. Services and Operations Management, 14 (2), 131-156.

Stachowski, C.A. (2011). Educational marketing: A review and implications for supporting practice in tertiary education. Educational Management Administration \& Leadership, 39(2), 186-204.

Sun, W., \& Pang, J. (2017). Service quality and global competitiveness: evidence from global service firm. Journal of Service Theory and Practice, 27(6), 1058-1080.

Tabaku, E., \& Mersini (Zerellari), M. (2013). An Overview of marketing means used by non-profit organizations: a detailed overview of NPOs operating in the district of Elbasan. Journal of Marketing and Management, 4 (2), 78-95.

Tajeddini, K., Trueman, M., \& Larsen, G. (2006). Examining the effect of market orientation on innovativeness. Journal of Marketing Management, 22, 5-6. 
Tan, H., Bashir, S., \& Tanaka, N. (2015). Skill use, skill deficits, and firm performance in formal sector enterprises: Evidence from the Tanzania enterprise skills survey. World Bank, Policy Research Working Paper 7672.

Tanzania Commission for Universities (TCU) (2018). Undergraduate students admission guidebook for higher learning institutions in Tanzania (For Holders of Ordinary Diploma or Equivalent Qualifications only) 2018/2019, Dar es Salaam, Tanzania.

Tanzania Commission for Universities (TCU) (2018). Undergraduate students admission guidebook for higher learning institutions in Tanzania (For Holders of Ordinary Diploma or Equivalent Qualifications only) 2018/2019.Dar es Salaam, Tanzania.

Tanzania Commission for Universities (TCU), (2019(c)). Handbook for standards \& guidelines for university education in Tanzania (3rd eds). Dar es Salaam, Tanzania UNESCO. (2020). UIS Stat http://data.uis.unesco.org/

United Nations Development Programme. (2014). Sustainable Development Goals 2030.

United Republic of Tanzania. (2005). University act. Dar es Salaam: Government Printer.

United Republic of Tanzania. (2013). University act general regulations. Dar es Salaam: Government Printer.

United Republic of Tanzania. (2014). Education and training policy. Dar es Salaam: Government Printer.

United Republic of Tanzania. (2014). Tanzania development vision 2025: National key result area education- big results now. Ofisi ya Rais Tume ya Mipango. Dar es Salaam

United Republic of Tanzania. (2014). The study on national skills development to facilitate Tanzania to become a strong and competitive economy by 2025. President's Office, Planning Commission, Dar es Salaam Tanzania.

United Republic of Tanzania. (2016). National five year development plan, 2016/17-2020/21. Ministry of Finance and Planning, Dar es Salaam, Tanzania.

United Republic of Tanzania. (2016). National five year development plan, 2016/17-2020/21. Ministry of Finance and Planning, Dar es Salaam, Tanzania.

Whang, U. (2017). Comparative advantage, product quality, and the competitiveness of firms. Journal of Korea Trade, 21(3), 174-190.

Yorke, M. (1999). Assuring quality and standards in globalized higher education. Quality Assurance in Education, 7(1), 14-24.

Zebal, M.A., Goodwin, D.R. (2012). Market orientation and performance in private universities. Marketing Intelligence \& Planning, 30(3), 339-357.

Zhang, L., Kara, A., Spillan, J.E., \& Mintu-Wimsatt, A. (2017). Exploring market orientation among Chinese small and medium-sized enterprises. Chinese Management Studies, 11(4), 617-636. 